\title{
Distribution and Cultivation Practices of Capsicum pubescens on the Islands of Java, Sumatra, and Sulawesi, Indonesia
}

\author{
YAMAMOTO Sota \\ (Kagoshima University), \\ DJARWANINGSIH Tutie \\ (Indonesian Institute of Sciences), \\ and WIRIADINATA Harry \\ (Indonesian Institute of Sciences)
}
I Introduction
II Distribution of C. pubescens on the Sumatra and Sulawesi islands
III Cultivation practices of C. pubescens

1. Large-scale C. pubescens cultivation

2. Medium- and small-scale C. pubescens cultivation

3. Cultivation of $C$. pubescens for personal consumption

4. Summary of C. pubescens cultivation in Indonesia

IV Conclusions

keywords : dispersal routes, ethnobotany, field and market surveys, tropical highlands, West Java

\section{Introduction}

Chili peppers (Capsicum spp.), which consists of approximately 25 species within the Solanaceae family, are native to tropical and temperate regions of the Americas (Eshbaugh, 1993). Four domesticated (C. annuum L., C. chinense Jacq., C. baccatum L., and C. pubescens Ruiz \& Pav) and one semi-domesticated (C. frutescens L.) species have been identified (Yamamoto and Nawata, 2006, 2009a; Yamamoto et al., 2007, 2008). Chili peppers are thought to have been introduced to Europe in 1493 by Columbus (Boswell, 1949), into Asia, via Africa and India in the late sixteenth century (Sturtevant, 1885; 
Kumazawa et al., 1954; Andrews, 1995: 43-47), and into Oceania during the early European era (Whistler, 1992: 131-132). However, details of its dispersal remain vague; many varieties of C. annuum have been globally produced and distributed, making it difficult to reconstruct its dispersal routes, whereas numerous local varieties of $C$. frutescens exist in Asia. Yamamoto (2011, 2012, 2013), Yamamoto and Nawata (2004, 2005, 2009b), and Yamamoto et al. (2011) studied the distribution and dispersal routes of C. frutescens in Southeast and East Asia and hypothesized that a rare phenotype of C. frutescens was introduced to the Philippines from the Americas via Oceania by Spanish traders between the mid-sixteenth and early nineteenth centuries. Thereafter, the phenotype would have dispersed throughout the insular region of Southeast Asia and to the Nansei Islands of Japan.

In Southeast and East Asia, C. annuum and C. frutescens are primarily cultivated as food (spices and vegetables) and medicine; the distribution of other species has been unknown until recently. However, Yamamoto et al. (2013) revealed that C. pubescens was introduced to Indonesia before 1916, likely during the Dutch era with other economically important plants, and that Bandung and the surrounding highlands in West Java and the Dieng Plateau in Central Java are the center of C. pubescens distribution on Java. In addition, they determined that $C$. pubescens was likely introduced from Bandung to the Dieng Plateau. Yamamoto et al. (2014) also found that C. chinense is distributed widely in Indonesia with several morphologically different fruit types on at least three major islands (Java, Kalimantan, and Sulawesi) and it was likely introduced before World War II. Moreover, this species is an important spice in South Sulawesi Province, as well as an ornamental plant throughout Indonesia. Finally, Capsicum in Indonesia seems to have more genetic diversity and breeding potential compared to other countries in Southeast and East Asia.

Four species of the genus Capsicum (C. annuum, C. frutescens, C. chinense, and C. pubescens) were confirmed in Indonesia by Yamamoto et al. (2013, 2014), but the distribution of $C$. pubescens except on Java and its cultivation practices in Indonesia are still unknown. Therefore, field and market surveys of C. pubescens were conducted in Java, Sumatra, and Sulawesi islands.

\section{Distribution of $C$. pubescens on the Sumatra and Sulawesi islands}

Capsicum pubescens likely originated in the middle elevations of Bolivia (Eshbaugh, 1975) and has been domesticated since around 6000 BC (DeWitt, 1999: 240-242). Heiser 
(1987: 25) noted that C. pubescens was the most common pepper among the Incas, as it still is in Cuzco, the former capital of the Incan empire. Morphologically, C. pubescens has numerous characteristics that distinguish it from other domesticated Capsicum species, such as purple flowers (sometimes with a white center), black seeds, hairy leaves, and ecological adaptations to tropical highland climates.

Yamamoto et al. (2013) determined its distribution on Java, but there is no information about it on the other Indonesian islands. To address this, we conducted fieldwork in North Sumatra (February 2015), West Sumatra (January-February 2013), Lampung and Bengkulu (October-November 2013), North Sulawesi (December 2014), and South Sulawesi (January-February 2014) provinces. The work consisted of plant surveys and local interviews in 48 markets.

Among the 48 markets, C. pubescens was found only in markets in Simpang and Muaralabuh in West Sumatra Province and Malino in South Sulawesi Province (Table 1, Fig. 1). In the Simpang market (Site M9), the price of C. pubescens (locally called lado kambuik) was IDR 20,000-25,000/kg (Fig. 2A-C) and among the 15 chili pepper vendors there, five sold C. pubescens. Its price was lower than that of C. annuum (IDR 20,000$30,000 / \mathrm{kg}$ ) and C. frutescens (IDR 40,000/kg). One vendor had been selling it for over 20 years, sold about $150 \mathrm{~kg}$ per week, and said that the fruit had been used by her grand mother's generation. We believe that C. pubescens was introduced to this region at least 40-50 years ago. In the Muaralabuh market (Site M10), the price of C. pubescens (locally called lado kambuik) was IDR 20,000/kg, lower than that of C. annuum (IDR 30,000$36,000 / \mathrm{kg}$ ) and C. frutescens (IDR 25,000-35,000/kg), and all fruits originated from Alahangpanjang (Solok, West Sumatra) (Fig. 2D-E). In the Sentral Malino market (Site M11), one vendor sold C. pubescens (locally called lombok katokkon or lombok paprika kecil) from Kanreapia (Gowa Regency, South Sulawesi) for IDR 15,000/kg and sold about $10 \mathrm{~kg}$ per week (Fig. 2F-G). Another vendor said that it was introduced within the last 10 years, but no others knew of its introduction.

Fruits of C. pubescens were not observed in the remaining 45 of the 48 markets; Pasar Buah dan Bunga and Pasar Sayur (Berastagi), Pasar Pangururan (Pangururan), Pasar Sidikalang (Sidikalang), Pasar Tebing Tinggi (Tebing Tinggi), Pasar Pematang Siantar (Pematang Siantar), Pasar Galige (Galige), Pasar Siborong Borong (Siborong Borong), Pasar Patapat (Patapat), Pasar Hindu (Medan), and Pusat Pasar (Medan) in North Sumatra Province; Pasar Raya Padang (Padang), Pasar Bawa (Bukittinggi), Pasar Sarilamak (Limapuluh Kota), Pasar Raya Solok (Solok), Pasar Logas (Muara Sijunjung), and Pasar Baru (Pulau Punjung) in West Sumatra Province; Pasar Gisting (Tanggamus), 


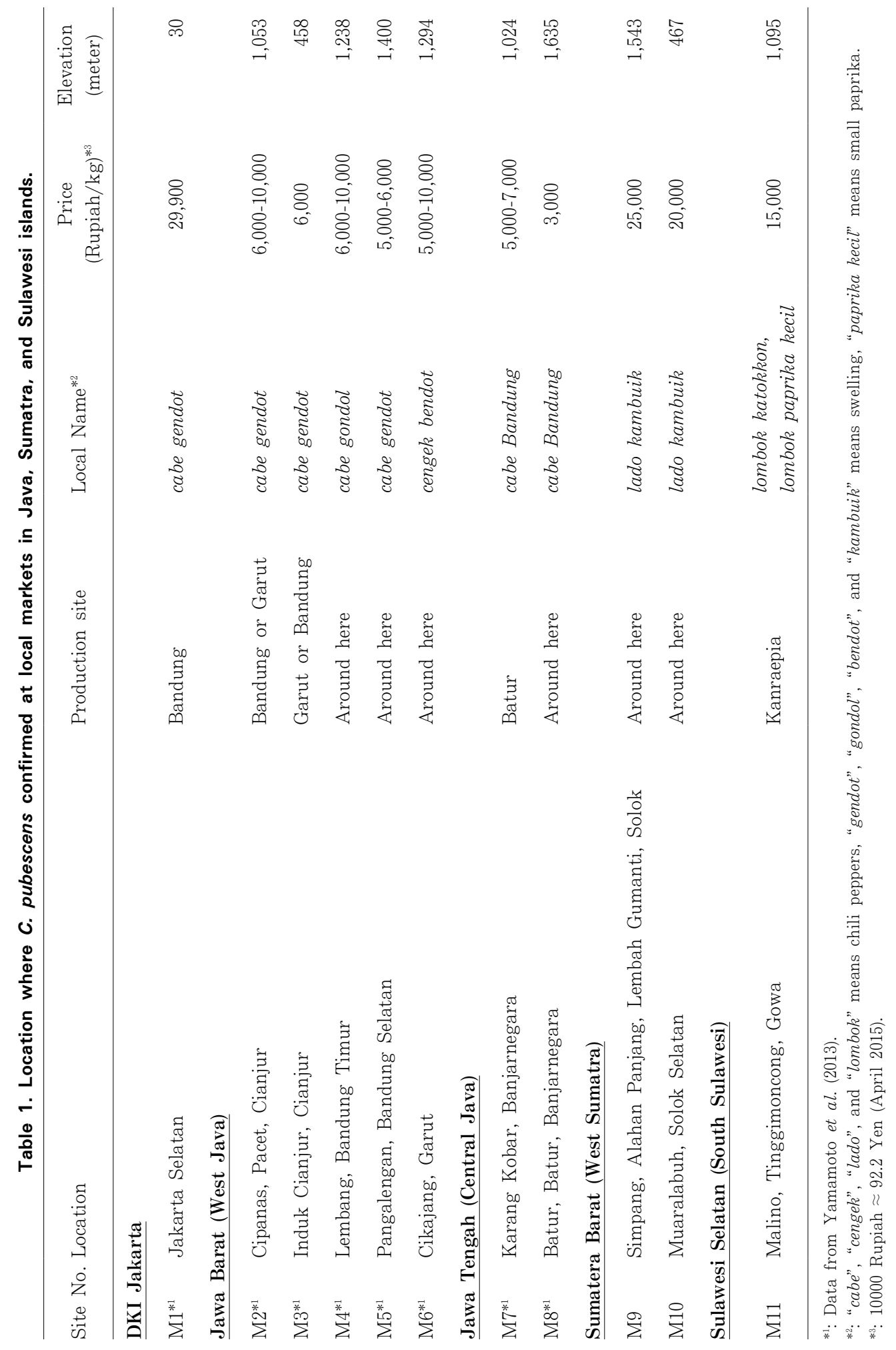




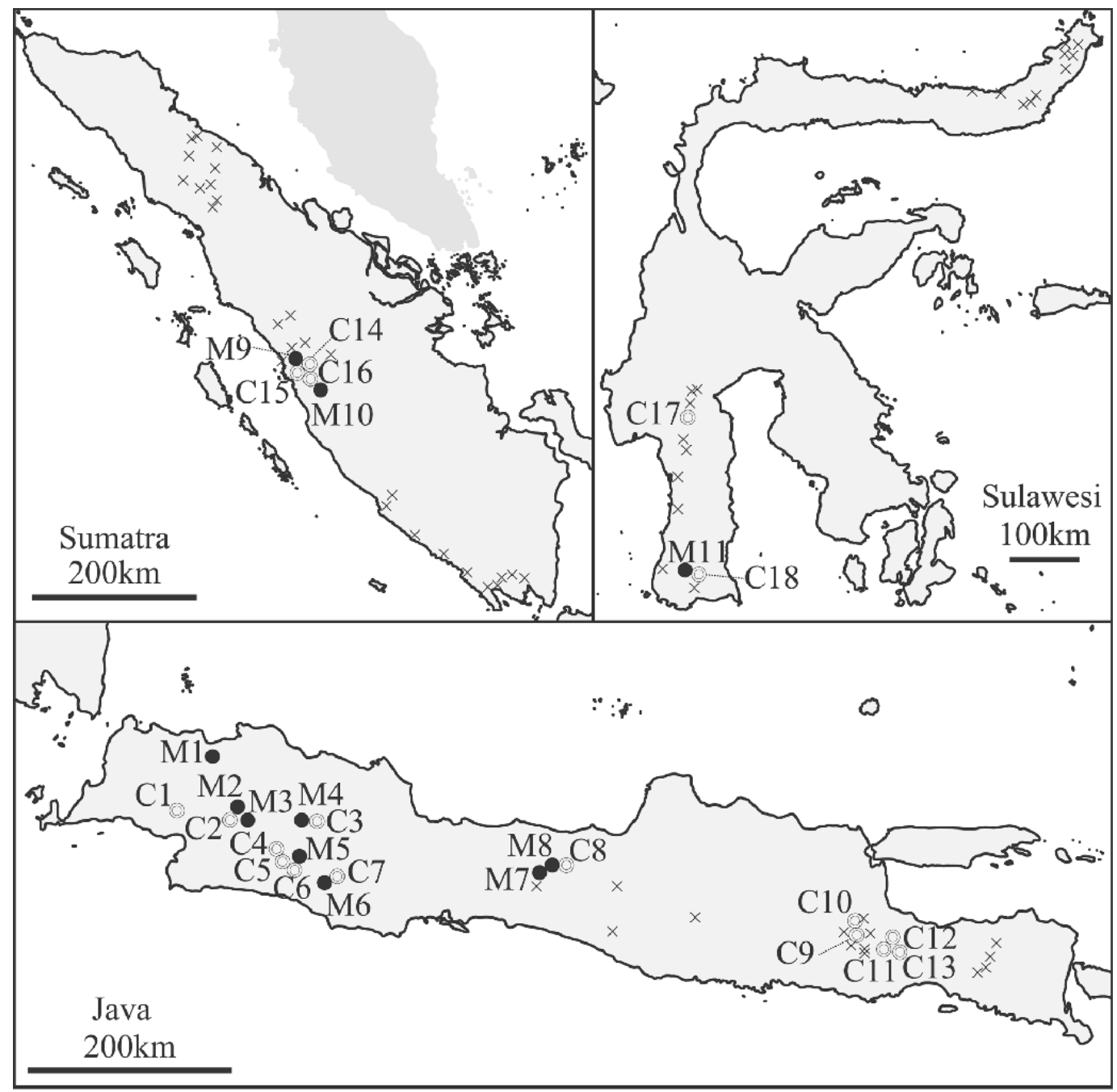

Fig. 1. Markets where C. pubescens was found (O), not found $(\times)$, and cultivated (@) in Java, Sumatra, and Sulawesi islands.

Pasar Kotaagung (Tanggamus), Pasar Way Batu (Krui), Pasar Negarabatin (Tanggamus), Pasar Pringsewu (Pringsewu), and Pasar Bandar Lampung (Lampung) in Lampung Province; Batu Lungun (Nasal, Kaur), Pasar Panorama (Bengkulu), Pasar Kepahiang (Kepahiang), and Pasar Ampera (Manna) in Bengkulu Province; Pasar Karombasan (Manado), Pasar Sangkup (Sangkup), Pasar Lolak (Lolak), Pasar Tradisional Poyowa Kecil (Kotamobagu), Guaan (Modayag), Pasar Modoinding (Modoinding), Pasar Beriman Tomohan (Beriman Tomohan), Pasar Tondano (Tondano), Pasar Langoan (Langoan), and Pasar Airmadidi (Airmadidi) in North Sulawesi Province; and Pasar Pare-Pare (Pare-Pare), Pasar Makale (Makale), Pasar Pagi (Rantepao), Pasar 


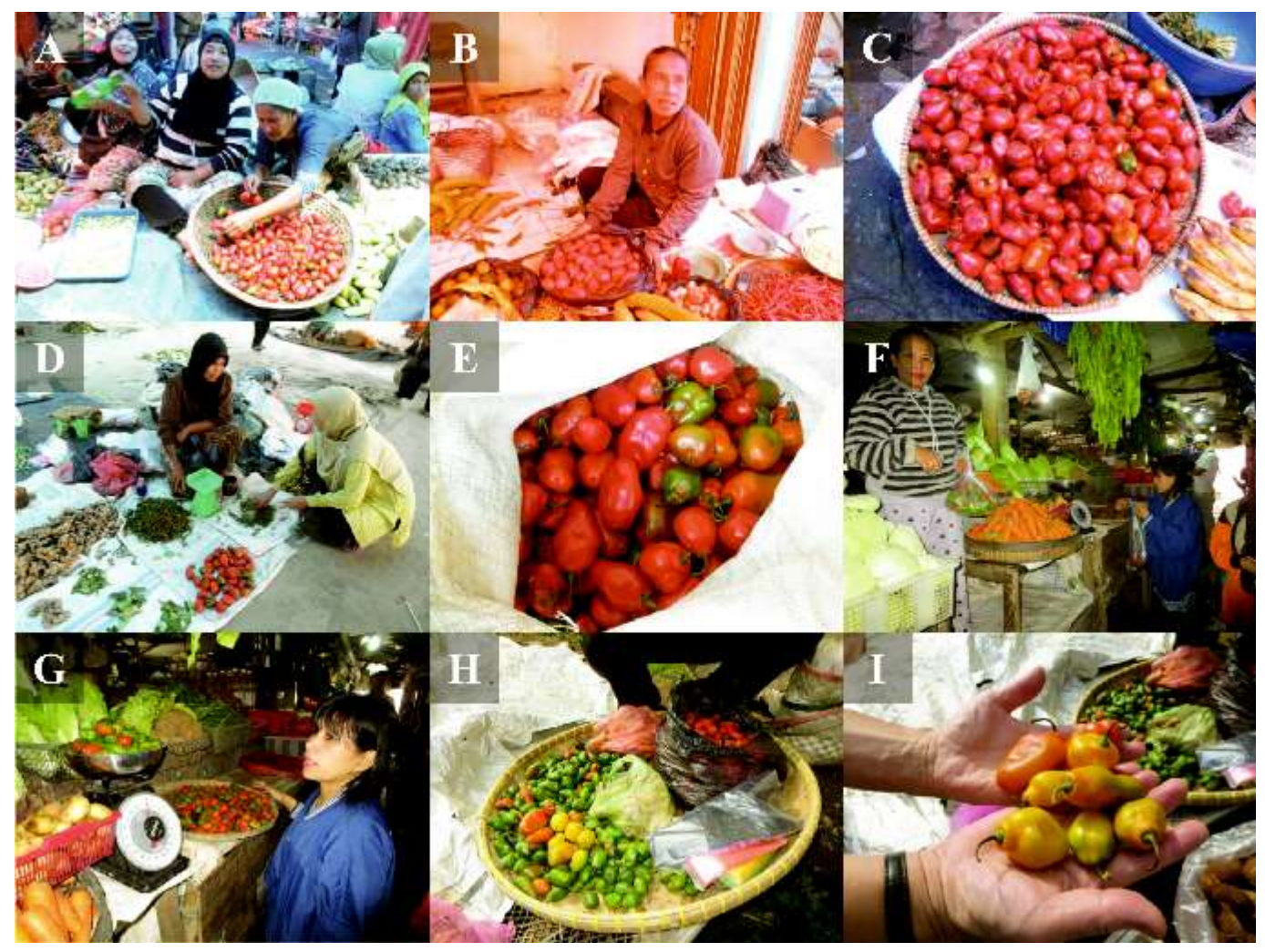

Fig. 2. Capsicum pubescens found in local markets. Pasar Simpang, Alahan Panjang, Lembah Gumanti, Solok, West Sumatra (A-C). Muaralabuh, Solok Selatan, West Sumatra (D-E). Malino, Tinggimoncong, Gowa, South Sulawesi (F-G). A yellow mature color fruit type of $C$. pubescens was newly found in Pasar Batur, Batur, Banjarnegara, Central Java (H-I).

Sore (Rantepao), Pasar Sentral Enrekang (Enrekang), Pasar Kabere (Kabere), Pasar Sentral Baru (Barru), Pasar Malakaji (Malakaji), and Pasar Terong (Makassar) in South Sulawesi Province.

A survey in West and Central Java in October 2014 revealed a new color type of $C$. pubescens in Pasar Batur (Site M8; Fig. 2H-I) characterized by a yellow mature fruit. This color type (called cabe Bandung) sold for IDR 10,000-12,000/kg and one vendor said that it was milder in flavor than the red type. People surveyed in the market gave contradictory information concerning the historical availability of the yellow type, as some said it was newly introduced to the area, while others said it was not. However, this type was not found in a 2011 survey (Yamamoto et al., 2013) and it remains unclear if it was introduced to Indonesia at the same time as the red type, or if it occurred as the result of a mutation after introduction. Further surveys are needed in Indonesia and the Americas to determine the distribution, diversity, and dispersal routes of yellow C. pubescens. 


\section{Cultivation practices of $C$. pubescens}

Capsicum pubescens is primarily cultivated in the Andes of South America, although it is also grown in Central America, where it was likely introduced in the twentieth century, as there is no prior record of the plant in the region (McLeod et al., 1982). Its cultivation status in the rest of the world is unknown (Basu and De, 2003) or very limited (Bosland and Votava, 2000: 19-20). Few studies have investigated its cultivation outside of the Americas, except for its introduction to Nagano, Japan (Matsushima et al., 2010). Thus, we surveyed West Java (January-February 2012), Central Java (March 2012), East Java (November 2012), North Sumatra (February 2015), West Sumatra (January-February 2013), North Sulawesi (December 2014), and South Sulawesi (January-February 2014) provinces to learn about its cultivation practices in Indonesia.

We confirmed its cultivation in Sukabumi, Cianjur, Bandung Timur, Bandung Selatan, and Garut in West Java; Banjarnegara in Central Java; Batu and Pasuruan in East Java; Solok in West Sumatra; and Tana Toraja and Gowa in South Sulawesi (Table 2, Fig. 1). The plant was found at a minimum of 1,400 $\mathrm{m}$ above sea level. At lower elevations, there were fields of both C. annuum and C. frutescens, as well as other highland crops such as tomato, potato, cabbage, green onion, shallots, carrots, beans, apples, and tea. In addition, there were highlands in North Sumatra and North Sulawesi suitable for cultivation of similar highland crops, but no C. pubescens was observed there in this study.

In Bandung Timur (Site C3), Bandung Selatan (Sites C4-C6), Garut (Site C7), and Banjarnegara (Site C8) fields of C. pubescens were more numerous and larger than those at other sites. In Sukabumi (Site C1), Cianjur (Site C2), Kota Batu (Site C9-C10), and Solok (Site C14-C16) C. pubescens was cultivated in medium- to small-scale fields. People in other regions generally cultivated it on the periphery of fields used for other crops or in home gardens primarily for personal consumption.

\section{Large-scale C. pubescens cultivation}

In Olan/Lapang, Barusuda, Cigedug, Garut (Site C7), a 37-year-old farmer of C. pubescens (locally called cengek bendot) had been cultivating the plant for 8 years, but people in the area had been growing it since her father, currently in his 60s, was young. She explained that in Garut Regency, West Java, C. pubescens is also cultivated in Cisurupan, Pasir Wangi, Samarang, Cilawu, Dayeuh Nanggung, and Gunung Satria.

This farmer grew C. pubescens in a nursery for 1 month (Fig. 3A) before transplanting 


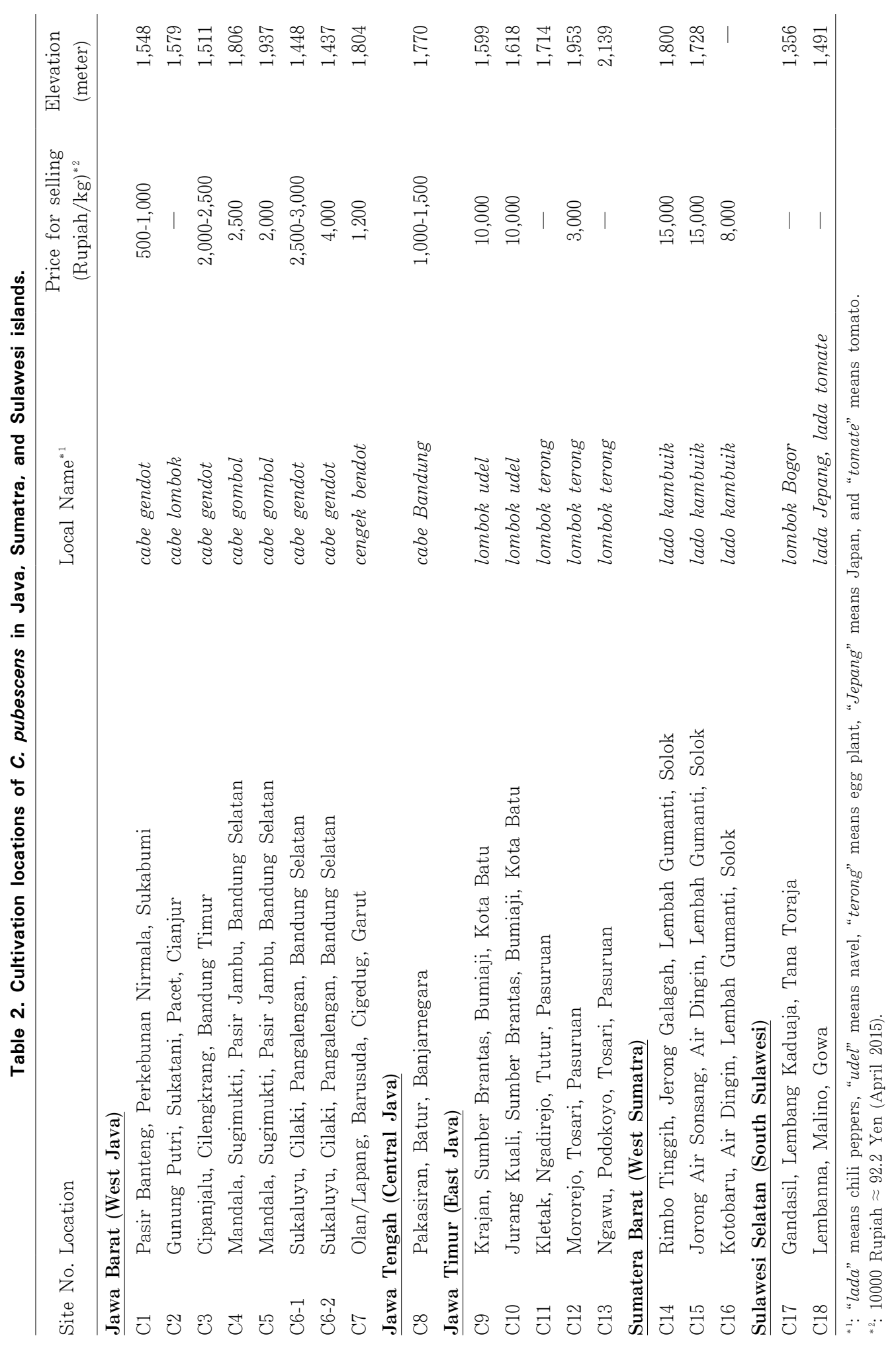




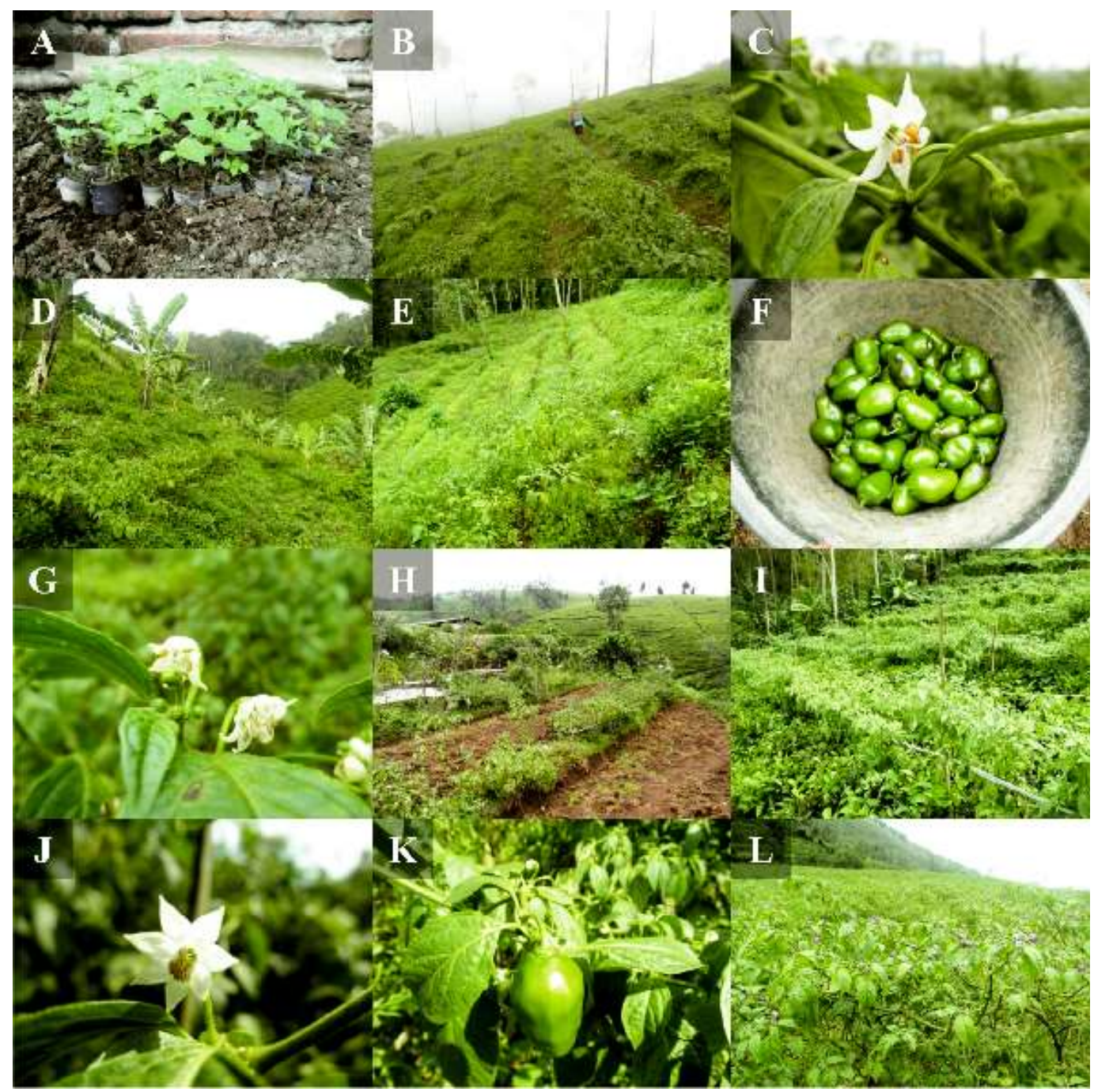

Fig. 3. Cultivation of C. pubescens on large-scale farms in Indonesia. A seedbed of C. pubescens (A), ridges of $C$. pubescens on a steep slope (B), and the white flower type of $C$. pubescens (C) in Olan/Lapang, Barusuda, Cigedug, Garut (Site C7). Capsicum pubescens cultivated among banana trees in Cipanjalu, Cilengkrang, Bandung Timur (Site C3). Cultivation among cabbages and tree seedlings (E), harvested C. pubescens fruits (F), and the white flower type of C. pubescens (G) in Mandala, Sugimukti, Pasir Jambu, Bandung Selatan (Site C4). Cultivation near a tea plantation in Mandala, Sugimukti, Pasir Jambu, Bandung Selatan (H: Site C5). Capsicum pubescens interspersed among tea trees in Sukaluyu, Cilaki, Pangalengan, Bandung Selatan (I: Site C6-1). Flower (J) and fruit (K) of the white flower type in Sukaluyu, Cilaki, Pangalengan, Bandung Selatan (Site C6-2). Capsicum pubescens field in Pakasiran, Batur, Banjarnegara (L: Site C8). 
the plants into fields. Harvesting began 6-7 months later and fruit was collected every 2 weeks for 2-3 years with weekly yields of about $0.5 \mathrm{~kg} /$ plant. Poultry manure was applied to fields before transplanting; chemical fertilizer ( $2 \mathrm{~g} /$ plant) was applied 1 month before harvesting began and subsequently after every harvest. No pesticides were used. Rows were spaced 100-120 cm apart and plants were spaced 50-60 cm apart within rows (Fig. 3B). As of January 2012, the farmer sold C. pubescens to middlemen or markets for IDR $1,200 / \mathrm{kg}$, and estimated that a 2 ha field would yield 1 ton of fruit each harvest.

According to a key published by the International Board for Plant Genetic Resources (1983), C. pubescens have characteristic dark seeds and a purple corolla on the flower, unique to the species. However, Yamamoto et al. (2013) reported a rare mutant with a completely white flower in Indonesia. The white flower type was confirmed at Site C7 (Fig. 3C), and the farmer said that the fruit and pericarp of this type was bigger and thicker than the normal purple flower type.

In Cipanjalu, Cilengkrang, Bandung Timur (Site C3), cultivation of C. pubescens (locally called cabe gendot) was observed near a quina (Cinchona spp.) plantation. A 67-year-old farmer who cultivated the plant among banana trees in a 0.25 ha field (Fig. 3D) said that C. pubescens was cultivated in the area since he was young, and that there were presently over 100 ha of $C$. pubescens fields near his village. The plant was also grown in the larger region surrounding his village, including Cibodas, Batu Loceng, Cikapundung, Asrama, and Pasir Angling, and middlemen gathered fruit from the region to bring to markets in Lembang and Bandung.

This farmer grew $C$. pubescens in a nursery for 1 month before transplanting them into fields. Harvesting began 5-6 months after transplantation and would happen every 2 weeks for 1 year. His field yielded 0.8-2 tons of fruit every 2 weeks. He applied chemical fertilizer (50 kg/0.25 ha; NPK 60-20-20 mixed with other chemical fertilizers) before transplanting and two to four times after flowering; pesticide was not used. As of March 2012, the farmer sold C. pubescens to middlemen or markets for IDR 2,000-2,500/kg. He had never seen the white flower type of C. pubescens.

In Mandala, Sugimukti, Pasir Jambu, Bandung Selatan (Site C4), a 53-year-old male and his wife from Cibodas cultivated approximately 1,000 C. pubescens (locally called cabe gombol) plants among cabbage plants and tree seedlings (Fig. 3E-F). They grew the plants in a nursery for 1 month before transplanting them into fields and harvesting began 5-6 months later. Fruit was collected every 2 weeks for 3 years and each plant produced $0.5-1 \mathrm{~kg}$ fruit per collection. Poultry manure (50 bags/1000 plants) was applied at the time of transplanting. Chemical fertilizer (1 gallon/1000 plants) was applied when 
plants reached a height of approximately $30 \mathrm{~cm}$, then again after two harvests and subsequently as deemed necessary. Pesticides were not used. We observed the white flower type of C. pubescens in the field (Fig. 3G), and the farmers indicated that its fruit was heavier than that of the purple flower type. As of March 2012, the farmers sold the fruits for IDR 2,500/kg. In addition, many bags of fruits were left along roads in the area for transport to markets.

At a nearby location in Mandala, Sugimukti, Pasir Jambu, Bandung Selatan (Site C5), a 47-year-old farmer cultivated approximately 500 plants of C. pubescens (locally called cabe gombol) near a tea plantation (Fig. $3 \mathrm{H})$. Cultivation methods were the same as those of the previously outlined nearby farm. Similarly, poultry manure (10 gallons/500 plants) was applied at the time of transplanting as well as after branching (15-20 gallons/500 plants). As of March 2012, this farmer sold the peppers to middlemen or markets for IDR $2,000 / \mathrm{kg}$. He was familiar with the white flower type of C. pubescens, but it was not present in his field.

In Ciwidey, near Sites C4 and C5, middlemen buying C. pubescens from farmers said that, within the region, the plant was grown specifically in Rancabolang, Patuha, Rancasuni, and Paranggong. They first began buying the peppers in 1990, initially purchasing about 2 ton/day; however, today they buy about 5 ton/day for about IDR $3,500 / \mathrm{kg}$ and sell it in Pasar Induk Caringin in Bandung. As of March 2012, transportation costs between Ciwidey and Bandung were IDR 200,000/1.5 ton of C. pubescens.

In Sukaluyu, Cilaki, Pangalengan, Bandung Selatan (Site C6-1), a 58-year-old farmer intercropped C. pubescens (locally called cabe gendot) with tea trees in a 3 ha field (Fig. 3I) and had been cultivating the plant for over 20 years. After 1 month of growth in a nursery, the farmer transplanted the plants into fields and initial harvests began 5 months later and occurred every 2 weeks for 1.5 years. Each plant yielded $0.5 \mathrm{~kg}$ per collection. Poultry manure (fist-sized amount/plant) was applied at the time of transplanting and after fruiting. Fungicides were occasionally applied to the tea trees in the field, but not directly to the C. pubescens plants. As of March 2012, the farmer sold the peppers to middlemen or markets for IDR 2,500-3,000/kg. He had seen the white flower type of C. pubescens, but it was not present in his field.

However, at another farm in Sukaluyu, Cilaki, Pangalengan, Bandung Selatan (Site C62), the white flower type made up an entire 0.5 ha plot (Fig. 3J) and was found scattered throughout adjacent fields on the farm. The farmer explained that internodes of the white flower type were longer than those of the purple flower type. At this farm, seeds were soaked in water for one night before sowing in a nursery, where they grew for 1-1.5 
months, at which point they were transplanted into fields. Harvest began 5-6 months after transplantation and occurred every 2 weeks for 2-3 years; yield was about $0.5 \mathrm{~kg} / \mathrm{plant}$ per collection. Poultry manure $(800 \mathrm{~kg} / \mathrm{ha})$ was applied at the time of transplanting, after branching and flowering, and once every 2 months after the initial harvest. Pesticides were applied once a week. The farmer sold the fruit for IDR 4,000/kg, as of March 2012.

At a farm in Pakasiran, Batur, Banjarnegara (Site C8), C. pubescens (locally called cabe Bandung) was sold to middlemen or markets for IDR 1,000-1,500/kg, as of January 2012. Rows of plants were spaced 90-100 cm apart, and within rows, plants were spaced $60 \mathrm{~cm}$ apart (Fig. 3L). The farmers had seen the white flower type of C. pubescens, but the plants were not found within the surveyed fields. Here, after 1 month in a nursery, plants were transplanted into fields and harvesting began 7 months later. Fruit was collected every 2 weeks. However, other information concerning cultivation practices on this farm was not reliable. In addition, many people grow C. pubescens for personal consumption in this area.

In Kopeng (near Site C8) in the Dieng Plateau, no C. pubescens cultivation was found. However, a person selling C. annuum and C. frutescens seedlings in the area said that he cultivated C. pubescens and had initially obtained seeds from a market in Pontianak, Kalimantan, 16 years ago.

\section{Medium- and small-scale $C$. pubescens cultivation}

In Pasir Banteng, Perkebunan Nirmala, Sukabumi (Site C1), a 43-year-old farmer had a 4 ha field of $C$. pubescens (locally called cabe gendot) in his village, which had already been established when he and his wife began farming it 17 years ago. The fruit sold for IDR $500-1,000 / \mathrm{kg}$ to a market in Bandung, but it was not very profitable because transportation fees cost IDR 500/kg (Fig. 4A). The plants were initially grown for 1 month in a nursery before being transplanted into fields where they grew for 5 months before the first harvest. Fruit was collected every 2 weeks for 3 years and yields were about 1.5 ton/ha per collection. Poultry manure (1 gallon/5-10 plants) was applied at the time of transplanting and pesticides were not used. The farmer was familiar with the white flower type of $C$. pubescens, but none were present in his field.

In Gunung Putri, Sukatani, Pacet, Cianjur (Site C2), a 52-year-old farmer said that C. pubescens had been cultivated there for his entire life and that plants reached heights of more than $2 \mathrm{~m}$ (Fig. 4B-C). Plants were grown in nurseries for 30-40 days, when they were transplanted into fields; initial harvests began 3-4 months later and were carried out every 2 weeks for at least 5 years. Thereafter, unspecified manure (300-400 gallons/ha) 


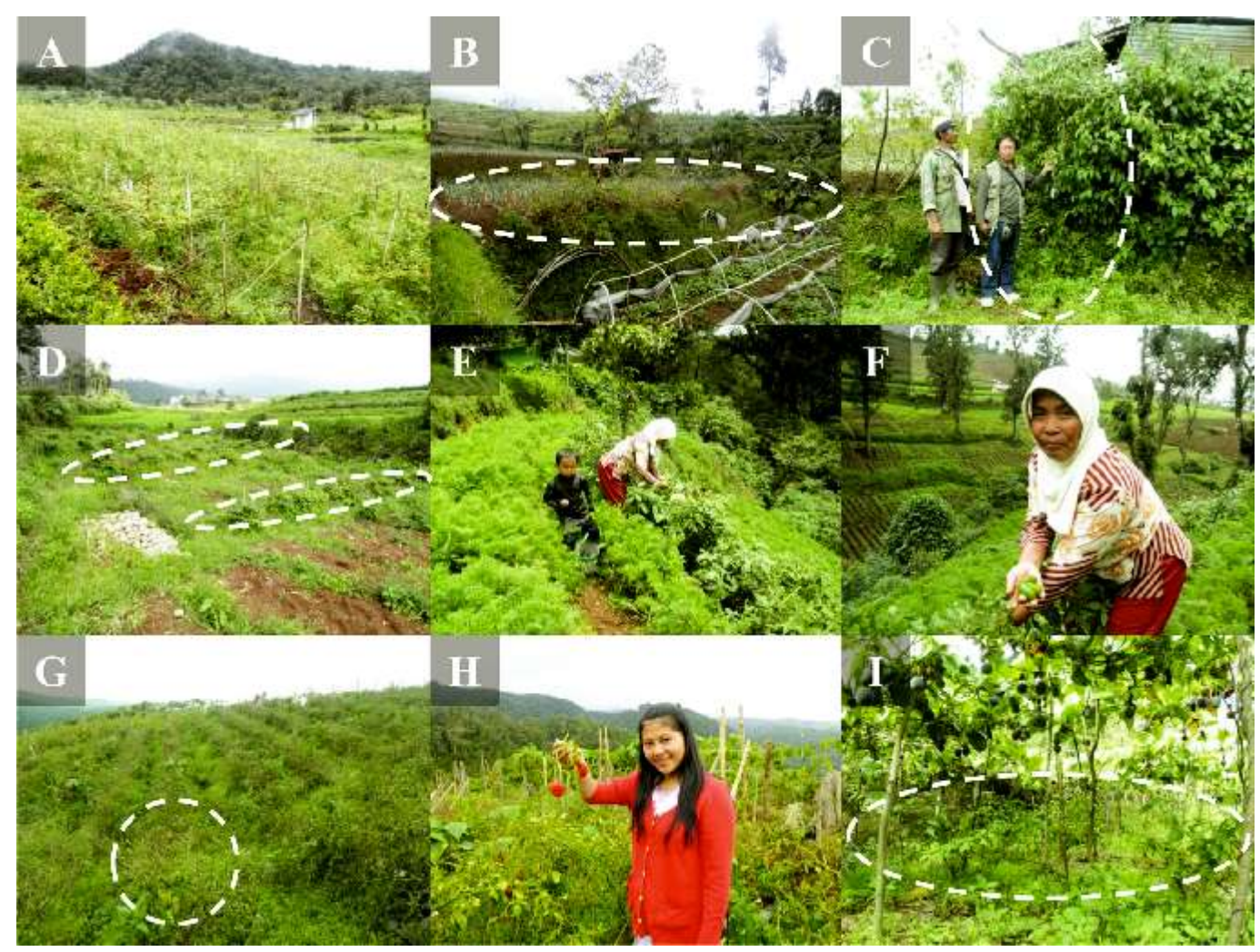

Fig. 4. Medium- and small-scale C. pubescens cultivation in Indonesia. A field in Pasir Banteng, Perkebunan Nirmala, Sukabumi (A: Site C1). Levee planting of C. pubescens (B) and a plant more than $2 \mathrm{~m}$ in height (C) in Gunung Putri, Sukatani, Pacet, Cianjur (Site C2). Plants on ridges between potato fields in Krajan, Sumber Brantas, Bumiaji, Kota Batu (D: Site C9). A female collecting fruits of C. pubescens planted on ridges of terraced carrot fields in Jurang Kuali, Sumber Brantas, Bumiaji, Kota Batu (E-F: Site 10). Cultivation of C. annuum with some C. pubescens plants $(G)$ and harvesting C. pubescens fruits $(H)$ in Rimbo Tinggih, Jerong Galagah, Lembah Gumanti, Solok (Site C14). Several rows of C. pubescens plants among passionfruit (Passiflora ligularis) plants in Jorong Air Sonsang, Air Dingin, Lembah Gumanti, Solok (I: Site C15).

was applied during transplanting three times a year. Pesticides were not used and the farmer had never seen the white flower type of C. pubescens.

In Krajan, Sumber Brantas, Bumiaji, Kota Batu (Site C9), a 52-year-old farmer planted C. pubescens (locally called lombok udel) on ridges between potato fields, which was a common practice in the area (Fig. 4D). Her grandparents planted C. pubescens as early as 1972 and she said that it was native to the area. As of November 2012, she sold the peppers for as much as IDR 10,000/kg. Plants were grown in nurseries for 1-2 months and initial harvests began 4 months after transplantation into fields. Harvests continued every week for 2 years and yielded $0.5 \mathrm{~kg} /$ plant per collection. Poultry manure (fist-sized 
amount/plant) was applied at the time of transplanting and after fruiting. Pesticides were not used. The farmer had never seen the white flower type of C. pubescens.

In Jurang Kuali, Sumber Brantas, Bumiaji, Kota Batu (Site C10), a 64-year-old farmer grew C. pubescens (locally called lombok udel) on ridges of terraced carrot fields and as of November 2012, sold the fruit for IDR 10,000/kg (Fig. 4E-F). Plants were grown in a nursery for 2 months and harvesting began 2-3 months following transplantation into fields. Fruit was collected once a week with an average yield of $0.2 \mathrm{~kg} / \mathrm{plant}$. Poultry manure (fist-sized amount/plant) was applied at the time of transplanting and pesticides were not used. She had never seen the white flower type of $C$. pubescens, but said that the plant had been cultivated in the area since she was young.

In Rimbo Tinggih, Jerong Galagah, Lembah Gumanti, Solok (Site C14), a 20-year-old farmer primarily cultivated C. annuum, but replaced them with C. pubescens (locally called lado kambuik) as the C. annuum plants died. In addition, she rotated other crops through the field, including other chili peppers, cabbages, potatoes, and shallots, according to their respective growing seasons. Capsicum pubescens plants were grown in a nursery for 2 weeks before being transplanted into fields. Then they were harvested every week for 2 years starting 6 months after transplantation. Weekly yields were $0.2 \mathrm{~kg} / \mathrm{plant}$. The farmer did not provide detailed information on fertilizer and pesticide use and had never seen the white flower type of C. pubescens. As of February 2013, she sold C. pubescens peppers for IDR $15,000 / \mathrm{kg}$ and C. annuum peppers for IDR 18,000/kg; she harvested up to $150 \mathrm{~kg}$ of the latter weekly.

In Jorong Air Sonsang, Air Dingin, Lembah Gumanti, Solok (Site C15), a 70-year-old farmer cultivated C. pubescens (locally called lado kambuik) among passionfruit (Passiflora ligularis) plants and a 95-year-old woman remembered C. pubescens cultivation when she was young. We believe that C. pubescens was introduced to this region at least 70-80 years ago. Here, the pepper plants were grown in a nursery for 2 months, at which point they were transplanted into fields; harvesting began 6 months later and continued weekly for 2 years. Weekly yields were $0.1-0.4 \mathrm{~kg} /$ plant and no fertilizers or pesticides were used. The farmers had never seen the white flower type of C. pubescens, and sold their product for IDR 15,000/kg as of February 2013.

In Kotobaru, Air Dingin, Lembah Gumanti, Solok (Site C16), a 37-year-old farmer said that up to $500 \mathrm{~kg}$ C. pubescens was sold from this village to Muaralabuh Market (Site M10) every week. In addition, the plant was cultivated in the nearby Rimbo Datar. This farmer grew C. pubescens in a nursery for 1 month before transplanting into a field. The initial harvest was 8 months after transplantation and continued weekly for 5 years. Her 
plants yielded a weekly total of 50-100 kg and she used no fertilizers or pesticides. She had never seen the white flower type of $C$. pubescens and sold her harvest for IDR $8,000 / \mathrm{kg}$, as of February 2013. An 85-year-old male standing next to her explained that C. pubescens had been cultivated in the area since he was young.

\section{Cultivation of $C$. pubescens for personal consumption}

In Kletak, Ngadirejo, Tutur, Pasuruan (Site C11), a 70-year-old farmer remembered $C$. pubescens cultivation from when he was young and explained that the plant is currently cultivated in numerous villages in the Mt. Bromo region, including in Cemorogading, Mororejo, Kalitejo, and Ngadiwono. In addition, a 41-year-old farmer cultivated C. pubescens on the periphery of a cabbage field for personal consumption and used the peppers in a chili paste called sambal terasi made from C. pubescens and C. frutescens fruits as well as shrimp paste and palm sugar (Fig. 5A-B). She directly sowed pepper seeds, and plants produced fruit for $4-5$ years. She used no fertilizers or pesticides and had never seen the white flower type of C. pubescens.

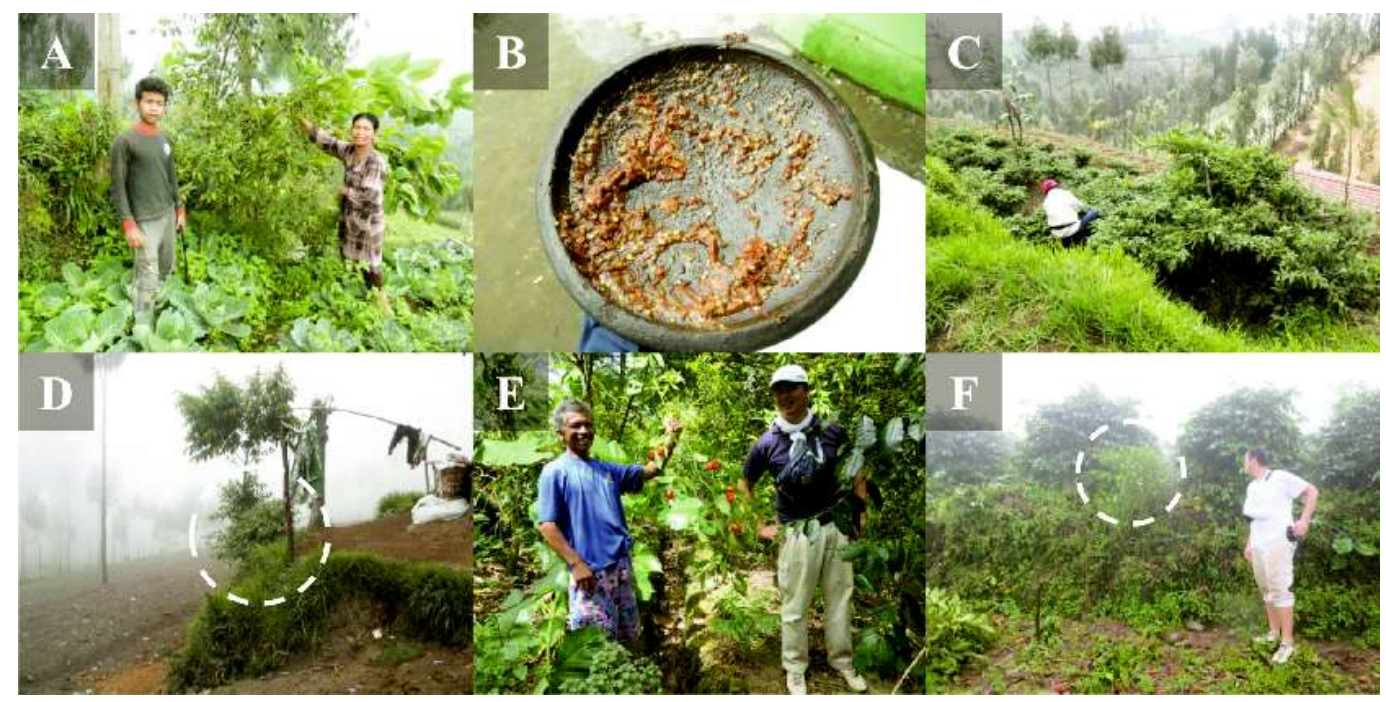

Fig. 5. Cultivation of C. pubescens for personal consumption in Indonesia. A plant of C. pubescens cultivated on the periphery of a cabbage field (A) and a homemade chili paste called sambal terasi made from C. pubescens and C. frutescens fruits as well as shrimp paste and palm sugar (B) in Kletak, Ngadirejo, Tutur, Pasuruan (Site C11). A small field of C. pubescens mainly for their own daily consumption and occasionally to sell fruit when there was a surplus in Mororejo, Tosari, Pasuruan (C: Site C12). A plant of C. pubescens cultivated in a homegarden in Ngawu, Podokoyo, Tosari, Pasuruan (D: Site C13). Plants cultivated among coffee plants and clove trees in Gandasil, Lembang Kaduaja, Tana Toraja (E: Site C17). Several C. pubescens plants in coffee fields in Lembanna, Malino, Gowa (F: Site C18). 
In Mororejo, Tosari, Pasuruan (Site C12), a 40-year-old farmer said that people in the village made chili paste from C. pubescens (locally called lombok terong) and only sold the fruit when there was an occasional surplus for about IDR 3,000/kg, as of November 2012 (Fig. 5C). Here, seeds were directly sowed and harvest began after 3 months and continued for 2 years. Poultry manure was applied at the time of plowing, but no pesticides were used. The farmer had never seen the white flower type of $C$. pubescens.

In Ngawu, Podokoyo, Tosari, Pasuruan (Site 13), a 40-year-old woman kept one plant of C. pubescens in her home garden for personal consumption (Fig. 5D). She directly sowed the seed and the initial harvest was 3-5 months later. Ashes were applied as fertilizer at plowing. No pesticides were used and she had never seen the white flower type of C. pubescens.

In Gandasil, Lembang Kaduaja, Tana Toraja (Site C17), a 50-year-old man cultivated C. pubescens (locally called lombok Bogor) among coffee plants and clove trees (Fig. 5E). He said that it was introduced to the area at least 10 years ago. Similarly, in Lembanna, Malino, Gowa (Site C18), a man in his 50s had several C. pubescens plants in coffee fields (Fig. 5F). However, no detailed information concerning its cultivation at these sites was collected, and none of these farmers had ever seen the white flower type of C. pubescens.

\section{Summary of C. pubescens cultivation in Indonesia}

Cultivation methods of $C$. pubescens did not greatly differ among 14 small- to largescale farming operations, except minor variation in fruit collection, fertilization, and pesticide application (Table 3). Plants were grown in a nursery for 1-1.5 months and harvesting began 3-8 months after transplantation into fields and generally continued for 2-3 years. Yields were approximately $0.5 \mathrm{~kg} /$ plant per harvest (Table 3). In West and Central Java provinces, fruit was collected every 2 weeks, whereas it was collected weekly in East Java and West Sumatra provinces. Fertilizer was applied at the time of transplantation, or after branching or flowering, and was generally applied once every 2 months after harvesting began. The amount, frequency, and types of fertilizer used depended on each farmer's income. Among 14 farmers, 11 did not apply pesticides, as the plants are resistant to diseases. Some farmers cultivated C. pubescens among tea trees, $C$. annuum, or other crops that required pesticide application and pesticides were also occasionally applied to C. pubescens in these fields (Table 3). In addition, we met five farmers who cultivated $C$. pubescens extensively mainly for their home consumption. The white flower type of C. pubescens was only recognized in West and Central Java and it is unclear if it was introduced to Indonesia or if it occurred as a mutation on Java. 
Table 3. Cultivation information of $C$. pubescens in Java, Sumatra, and Sulawesi islands.

\begin{tabular}{|c|c|c|c|c|c|c|c|c|}
\hline \multirow{2}{*}{$\begin{array}{l}\text { Site } \\
\text { No. }\end{array}$} & \multirow{2}{*}{$\begin{array}{l}\text { Informant } \\
\text { (sex, age) }\end{array}$} & \multicolumn{6}{|c|}{ Basic information on cultivation of $C$. pubescens } & \multirow{2}{*}{$\begin{array}{l}\text { White flower } \\
\text { of C. pubescens }\end{array}$} \\
\hline & & Nursery & Harvest & $\begin{array}{c}\text { Fruit } \\
\text { picking }\end{array}$ & Yield & Fertilizer & Pesticide & \\
\hline $\mathrm{C} 1$ & Male, 43 & 1 month & $\begin{array}{l}5 \text { month } \\
\text { to } 3 \text { year }\end{array}$ & $\begin{array}{l}\text { Once in } \\
2 \text { weeks }\end{array}$ & $1.5 \mathrm{t} / \mathrm{h}$ & $\begin{array}{l}\text { Poultry manure ( } 1 \text { gallon } / 5-10 \\
\text { plants) applied at transplanting }\end{array}$ & No use & $\begin{array}{l}\text { Known } \\
\text { to farmers }\end{array}$ \\
\hline $\mathrm{C} 2$ & Male, 52 & $30-40$ days & $\begin{array}{l}3-4 \text { month } \\
\text { to }+5 \text { year }\end{array}$ & $\begin{array}{l}\text { Once in } \\
2 \text { weeks }\end{array}$ & n.a. ${ }^{* 1}$ & $\begin{array}{l}\text { Any manure ( } 300-400 \text { gallons } / \text { ha) } \\
\text { applied at transplanting; any ma- } \\
\text { nure applied three times a year } \\
\text { (details unknown) }\end{array}$ & No use & $\begin{array}{l}\text { Unknown } \\
\text { to farmers }\end{array}$ \\
\hline C3 & Male, 67 & 1 month & $\begin{array}{l}5-6 \text { month } \\
\text { to } 1 \text { year }\end{array}$ & $\begin{array}{l}\text { Once in } \\
2 \text { weeks }\end{array}$ & $0.8-2 \mathrm{t} / \mathrm{ha}$ & $\begin{array}{l}\text { Chemical fertilizer }(200 \mathrm{~kg} / \mathrm{ha} \text { ) ap- } \\
\text { plied at transplanting; the same } \\
\text { amount applied after flowering } \\
\text { (chemical fertilizer applied totally } \\
\text { three to five times a cropping } \\
\text { season) }\end{array}$ & No use & $\begin{array}{l}\text { Unknown } \\
\text { to farmers }\end{array}$ \\
\hline $\mathrm{C} 4$ & Male, 53 & 1 month & $\begin{array}{l}5-6 \text { month } \\
\text { to } 3 \text { year }\end{array}$ & $\begin{array}{l}\text { Once in } \\
2 \text { weeks }\end{array}$ & $\begin{array}{l}0.5-1 \mathrm{~kg} / \\
\text { plant }\end{array}$ & $\begin{array}{l}\text { Poultry manure (50 bags } / 1000 \\
\text { plants) applied at transplanting; } \\
\text { chemical fertilizer ( } 1 \text { gallon } / 1000 \\
\text { plants) applied at nearly } 30 \mathrm{~cm} \\
\text { plant height; the same amount of } \\
\text { chemical fertilizer applied after } \\
\text { two times of fruit collection; } \\
\text { after that, chemical fertilizer ap- } \\
\text { plied as needed }\end{array}$ & No use & $\begin{array}{l}\text { Confirmed } \\
\text { in the field }\end{array}$ \\
\hline C5 & Male, 47 & 1 month & $\begin{array}{l}5-6 \text { month } \\
\text { to } 3 \text { year }\end{array}$ & $\begin{array}{l}\text { Once in } \\
2 \text { weeks }\end{array}$ & $\begin{array}{l}0.5 \mathrm{~kg} / \\
\text { plant }\end{array}$ & $\begin{array}{l}\text { Poultry manure (10 gallons/500 } \\
\text { plants) applied at transplanting; } \\
\text { poultry } \quad \text { manure }(15-20 \\
\text { gallons } / 500 \text { plants) applied after } \\
\text { branching }\end{array}$ & No use & $\begin{array}{l}\text { Known } \\
\text { to farmers }\end{array}$ \\
\hline C6-1 & Male, 58 & 1 month & $\begin{array}{l}5 \text { month } \\
\text { to } 1.5 \text { year }\end{array}$ & $\begin{array}{l}\text { Once in } \\
2 \text { weeks }\end{array}$ & $\begin{array}{l}0.5 \mathrm{~kg} / \\
\text { plant }\end{array}$ & $\begin{array}{l}\text { Poultry manure (fist-sized/plant) } \\
\text { applied at transplanting; the } \\
\text { same amount applied after fruit- } \\
\text { ing }\end{array}$ & $\begin{array}{c}\text { Use } \\
\text { (fungicides) }\end{array}$ & $\begin{array}{l}\text { Known } \\
\text { to farmers }\end{array}$ \\
\hline C6-2 & Male, 45 & 1-1.5 month & $\begin{array}{l}\text { 5-6 month } \\
\text { to } 2-3 \text { year }\end{array}$ & $\begin{array}{l}\text { Once in } \\
2 \text { weeks }\end{array}$ & $\begin{array}{l}0.5 \mathrm{~kg} / \\
\text { plant }\end{array}$ & $\begin{array}{l}\text { Poultry manure }(800 \mathrm{~kg} / \mathrm{ha}) \text { after } \\
\text { transplanting; the same amount } \\
\text { applied after branching, flower- } \\
\text { ing, once every two months after } \\
\text { harvesting }\end{array}$ & Use & $\begin{array}{l}\text { Confirmed } \\
\text { in the field }\end{array}$ \\
\hline $\mathrm{C} 7$ & Female, 37 & 1 month & $\begin{array}{l}\text { 6-7 month } \\
\text { to } 2-3 \text { year }\end{array}$ & $\begin{array}{l}\text { Once in } \\
2 \text { weeks }\end{array}$ & $\begin{array}{l}0.5 \mathrm{~kg} / \\
\text { plant }\end{array}$ & $\begin{array}{l}\text { Poultry manure (details un- } \\
\text { known) applied before transplant- } \\
\text { ing; chemical fertilizer ( } 2 \mathrm{~g} / \text { plant) } \\
\text { applied once a month before har- } \\
\text { vesting and after every harvest- } \\
\text { ing }\end{array}$ & No use & $\begin{array}{l}\text { Confirmed } \\
\text { in the field }\end{array}$ \\
\hline $\mathrm{C} 8$ & Male, 50's & 1 month & $\begin{array}{l}7 \text { month } \\
\text { to n.a. }\end{array}$ & $\begin{array}{l}\text { Once in } \\
2 \text { weeks }\end{array}$ & n.a. ${ }^{* 1}$ & n.a. ${ }^{* 1}$ & No use & $\begin{array}{l}\text { Known } \\
\text { to farmers }\end{array}$ \\
\hline C9 & Female, 50 & 1-2 month & $\begin{array}{l}4 \text { month } \\
\text { to } 2 \text { year }\end{array}$ & $\begin{array}{l}\text { Once } \\
\text { a week }\end{array}$ & $\begin{array}{l}0.5 \mathrm{~kg} / \\
\text { plant }\end{array}$ & $\begin{array}{l}\text { Poultry manure (fist-sized/plant) } \\
\text { applied at transplanting; the } \\
\text { same amount applied after fruit- } \\
\text { ing }\end{array}$ & No use & $\begin{array}{l}\text { Unknown } \\
\text { to farmers }\end{array}$ \\
\hline $\mathrm{C} 10$ & Female, 64 & 2 month & $\begin{array}{l}2-3 \text { month } \\
\text { to } 2 \text { year }\end{array}$ & $\begin{array}{l}\text { Once } \\
\text { a week }\end{array}$ & $\begin{array}{l}0.2 \mathrm{~kg} / \\
\text { plant }\end{array}$ & $\begin{array}{l}\text { Poultry manure (fist-sized/plant) } \\
\text { applied at transplanting }\end{array}$ & No use & $\begin{array}{l}\text { Unknown } \\
\text { to farmers }\end{array}$ \\
\hline C11 & Female, 41 & $\begin{array}{l}\text { Direct } \\
\text { sowing }\end{array}$ & to $4-5$ years & $\mathrm{FU}^{* 2}$ & $\mathrm{FU}^{* 2}$ & No use & No use & $\begin{array}{l}\text { Unknown } \\
\text { to farmers }\end{array}$ \\
\hline $\mathrm{C} 12$ & Male, 40 & $\begin{array}{l}\text { Direct } \\
\text { sowing }\end{array}$ & $\begin{array}{l}3 \text { month } \\
\text { to } 2 \text { year }\end{array}$ & $\mathrm{FU}^{* 2}$ & $\mathrm{FU}^{* 2}$ & $\begin{array}{l}\text { Poultry manure applied at plow- } \\
\text { ing }\end{array}$ & No use & $\begin{array}{l}\text { Unknown } \\
\text { to farmers }\end{array}$ \\
\hline $\mathrm{C} 13$ & Female, 40 & Direct & $\begin{array}{l}3-5 \text { month } \\
\text { to } 5 \text { year }\end{array}$ & $\mathrm{FU}^{* 2}$ & $\mathrm{FU}^{* 2}$ & Ashes applied at plowing & No use & $\begin{array}{l}\text { Unknown } \\
\text { to farmers }\end{array}$ \\
\hline C14 & Female, 20 & 2 weeks & $\begin{array}{l}6 \text { month } \\
\text { to } 2 \text { year }\end{array}$ & $\begin{array}{l}\text { Once } \\
\text { a week }\end{array}$ & $\begin{array}{l}0.2 \mathrm{~kg} / \\
\text { plant }\end{array}$ & $\mathrm{Use}^{* 3}$ & $\mathrm{Use}^{* 3}$ & $\begin{array}{l}\text { Unknown } \\
\text { to farmers }\end{array}$ \\
\hline C15 & Male, 70 & 2 month & $\begin{array}{l}6 \text { month } \\
\text { to } 2 \text { year }\end{array}$ & $\begin{array}{l}\text { Once } \\
\text { a week }\end{array}$ & $0.1-0.4 \mathrm{~kg}$ & No use & No use & $\begin{array}{l}\text { Unknown } \\
\text { to farmers }\end{array}$ \\
\hline C16 & Female, 37 & 1 month & $\begin{array}{l}8 \text { month } \\
\text { to } 5 \text { year }\end{array}$ & $\begin{array}{c}\text { Once } \\
\text { a week }\end{array}$ & $\begin{array}{l}50-100 \mathrm{~kg} \\
/ \text { week }\end{array}$ & No use & No use & $\begin{array}{l}\text { Unknown } \\
\text { to farmers }\end{array}$ \\
\hline $\mathrm{C} 17$ & Male, 50 & $\begin{array}{l}\text { Direct } \\
\text { sowing }\end{array}$ & n.a. ${ }^{* 1}$ & $\mathrm{FU}^{* 2}$ & $\mathrm{FU}^{* 2}$ & No use & No use & $\begin{array}{l}\text { Unknown } \\
\text { to farmers }\end{array}$ \\
\hline C18 & Male, 50’s & $\begin{array}{l}\text { Direct } \\
\text { sowing }\end{array}$ & n.a. ${ }^{* 1}$ & $\mathrm{FU}^{* 2}$ & $\mathrm{FU}^{* 2}$ & No use & No use & $\begin{array}{l}\text { Unknown } \\
\text { to farmers }\end{array}$ \\
\hline
\end{tabular}

*1: We did not get reliable information.

*2: Mainly for family use.

*3: No detailed data. 


\section{Conclusions}

This study confirms that C. pubescens is cultivated on Java, Sumatra, and Sulawesi islands. In addition, we found that Java is the center of C. pubescens cultivation and diversity, as it is farmed on a large scale in West and Central Java provinces and the white flower type was only recognized there. Moreover, a yellow fruit type of the pepper was only found in Central Java. Finally, a local name for the plant in South Sulawesi Province was "lombok Bogor," suggesting that it was introduced from Bogor in West Java Province. These observations agree with the hypothesis of Yamamoto et al. (2013), which suggests that C. pubescens was first introduced to Bandung, West Java, with other economically important highlands plants during the Dutch era. However, to better understand the introduction of this species to Indonesia, it is necessary to analyze the genetic relationships between plants in Indonesia and the Americas.

\section{Acknowledgments}

We thank Dr. Siti Nuramaliati Prijono, Research Center for Biology, LIPI, and Dr. Herman Hidayat, Research Center for Society and Culture, LIPI, for writing recommendation letters to the State Ministry of Research and Technology (RISTEK) to obtain a research permit for this study (Research Permit Number: 4/TKPIPA/FRP/SM/IV/2011). We are also grateful to RISTEK for providing us with opportunities for the investigation. This work was partly supported by the Japan Society for the Promotion of Science (Project code: No. 24710290, No. 23248055, and 15K16585).

\section{References}

Andrews, J. 1995. Peppers-the Domesticated Capsicums, New Edition. 274 pp., University of Texas Press, Austin.

Basu, S. K. and De, A. K. 2003. Capsicum: Historical and botanical perspectives. In: Capsicum: The Genus Capsicum (De, A. K. ed.), 1-15, Taylor \& Francis, London.

Bosland, P. W. and Votava, E. J. 2000. Peppers: Vegetable and Spice Capsicums. 204 pp., CABI publishing, Oxon, UK and New York.

Boswell, V. R. 1949. Garden pepper, both a vegetable and a condiment. In our vegetable travelers. National Geographer, 96: 145-217.

DeWitt, D. 1999. The Chile Pepper Encyclopedia: Everything You'll Ever Need to Know About Hot Peppers, with More Than 100 Recipes. 338 pp., William Morrow and Company, Inc., New York. 
Eshbaugh, W. H. 1975. Genetic and biochemical systematic studies of chili peppers (CapsicumSolanaceae). Bulletin of the Torrey Botanical Club, 102: 396-403.

Eshbaugh, W. H. 1993. Peppers: History and exploitation of a serendipitous new crop discovery. In: New Crops (Janick, J. and Simon, J. E. eds.), 132-139, Wiley, New York.

Heiser, C. B. 1987. The Fascinating World of the Nightshades: Tobacco, Mandrake, Potato, Tomato, Pepper, Eggplant, etc. 200 pp., Dover Publications, New York.

International Board for Plant Genetic Resources 1983. Genetic Resources of Capsicum: A Global Plan of Action. 49 pp., IBPGR Secretariat, Rome.

Kumazawa, S., Ohara, T. and Niiuchi, K. 1954. The differentiation of varieties of peppers in Japan. Journal of the Japanese Society for Horticultural Science, 23: 152-158 (in Japanese with English Summary).

Matsushima, K., Saritnum, O., Hamauzu, Y., Adachi, R., Harada, K., Minami, M. and Nemoto, K. 2010. Evaluation of the functional properties of chili pepper varieties 'rocoto' (Capsicum pubescens Ruiz. \& Pav.) and 'botankoshou' (C. annuum L.), which are suitable for growing in cool areas. Horticultural Research (Japan), 9(2): 243-248 (in Japanese with English Summary).

McLeod, M. J., Guttman, S. I. and Eshbaugh, W. H. 1982. Early evolution of chili peppers (Capsicum). Economic Botany, 36: 361-368.

Sturtevant, E. L. 1885. Kitchen garden esculents of American origin. II. Peppers. American Naturalist, 19: 542-553.

Whistler, W. A. 1992. Polynesian Herbal Medicine. 238 pp., National Tropical Botanical Garden, Kauai.

Yamamoto, S. 2011. Use of Capsicum frutescens on Pohnpei Island, Mokil Atoll, and Pingelap Atoll, Federated States of Micronesia. People and Culture in Oceania, 27: 87-104.

Yamamoto, S. 2012. Use of Capsicum frutescens in Chuuk Atoll, Federated States of Micronesia. Tropical Agriculture and Development, 56: 151-158.

Yamamoto, S. 2013. Use of Capsicum on Kosrae Island, Federated States of Micronesia. South Pacific Studies, 33: 87-99.

Yamamoto, S., Djarwaningsih, T. and Wiriadinata, H. 2013. Capsicum pubescens (Solanaceae) in Indonesia: Its history, taxonomy, and distribution. Economic Botany, 67: 161-170.

Yamamoto, S., Djarwaningsih, T. and Wiriadinata, H. 2014. History and distribution of Capsicum chinense in Indonesia. Tropical Agriculture and Development, 58: 94-101.

Yamamoto, S., Matsumoto, T. and Nawata, E. 2011. Capsicum use in Cambodia: The continental region of Southeast Asia is not related to the dispersal route of C. frutescens in the Ryukyu Islands. Economic Botany, 65: 27-43.

Yamamoto, S., Misumi, M. and Nawata, E. 2007. Effects of various photoperiods on flowering in Capsicum frutescens and C. annuum. Environment Control in Biology, 45: 133-142.

Yamamoto, S., Misumi, M. and Nawata, E. 2008. Effects of photoperiod on vegetative growth, flowering and fruiting of Capsicum frutescens L. and C. annuum L. in Japan. Environment Control in Biology, 46: 39-47.

Yamamoto, S. and Nawata, E. 2004. Morphological characters and numerical taxonomic study of Capsicum frutescens in Southeast and East Asia. Tropics, 14: 111-121. 
Yamamoto, S. and Nawata, E. 2005. Capsicum frutescens L. in Southeast and East Asia, and its dispersal routes into Japan. Economic Botany, 59: 18-28.

Yamamoto, S. and Nawata, E. 2006. The germination characteristics of Capsicum frutescens L. on the Ryukyu Islands and the domestication stages of C. frutescens L. in Southeast Asia. Japanese Journal of Tropical Agriculture, 50: 142-153.

Yamamoto, S. and Nawata, E. 2009a. Effect of root zone on flower bud formation and flowering of genus Capsicum. Tropical Agriculture and Development, 53: 55-58.

Yamamoto, S. and Nawata, E. 2009b. Use of Capsicum frutescens L. by the indigenous peoples of Taiwan and the Batanes Islands. Economic Botany, 63: 43-59. 


\title{
Distribution and Cultivation Practices of Capsicum pubescens on the Islands of Java, Sumatra, and Sulawesi, Indonesia
}

\author{
YAMAMOTO Sota \\ (Kagoshima University), \\ DJARWANINGSIH Tutie \\ (Indonesian Institute of Sciences), \\ and WIRIADINATA Harry \\ (Indonesian Institute of Sciences)
}

keywords : dispersal routes, ethnobotany, field and market surveys, tropical highlands, West Java

\begin{abstract}
Capsicum pubescens originated in mid-elevation Bolivia and is still primarily cultivated in South and Central America, although its cultivation was recently confirmed in highlands on the island of Java, Indonesia. However, its distribution and local cultivation practices elsewhere in Indonesia are unknown. To address this, we conducted field and market surveys of C. pubescens on the islands of Java, Sumatra, and Sulawesi and confirmed its distribution in the highlands of West Sumatra and South Sulawesi provinces. It seems that C. pubescens was introduced to West Sumatra Province at least 50-80 years ago. Moreover, in the province of Central Java, we found a new phenotype of C. pubescens characterized by a yellow fruit. The white flower type of C. pubescens was only observed in West and Central Java. There was no evidence of C. pubescens in North Sumatra and North Sulawesi provinces, despite the highlands being seemingly suitable for its growth. Fields of C. pubescens were numerous and large in West and Central Java provinces, while it was cultivated in middle- and small-scale farms or in home gardens in East Java, West Sumatra, and South Sulawesi provinces. Cultivation methods did not differ greatly between large and small farming operations, except in terms of fertilization, fruit harvesting, and pesticide application. We believe that C. pubescens was first introduced to Indonesia in West Java, which remains the center of its cultivation and diversity.
\end{abstract}

